\title{
Recommendations for anticoagulation and thrombosis management of pediatric COVID-19 - a single center multidisciplinary consensus
}

\author{
Michele Loi ${ }^{1}$, Brian Branchford ${ }^{1}$, John Kim ${ }^{1}$, Chelsea Self ${ }^{1}$, and Rachelle Nuss ${ }^{2}$ \\ ${ }^{1}$ Children's Hospital Colorado \\ ${ }^{2}$ University of Colorado Denver
}

May 18, 2020

\begin{abstract}
Coronavirus Disease 2019 (COVID-19) is associated with hypercoagulability and adult guidelines have been published regarding the evaluation and anticoagulation of adults infected with COVID-19. Pediatric resources on this topic are lacking. We developed preliminary recommendations for the thrombotic evaluation and anticoagulation treatment for children hospitalized with COVID-19 by reviewing the available literature and guidelines and adapting the information for the pediatric population through a multidisciplinary consensus driven approach.
\end{abstract}

\section{Hosted file}

may15manu.pdf available at https://authorea.com/users/323021/articles/451956-recommendationsfor-anticoagulation-and-thrombosis-management-of-pediatric-covid-19-a-single-centermultidisciplinary-consensus 
Table 1. Recommendations for evaluation, prevention and treatment of pediatric COVID-19 related VTE

\begin{tabular}{|c|c|c|}
\hline $\begin{array}{l}\text { CLINICAL } \\
\text { PARAMETER }\end{array}$ & PEDIATRIC RECOMMENDATIONS & OTHER CONSIDERATIONS \\
\hline $\begin{array}{l}\text { Laboratory } \\
\text { evaluation and } \\
\text { monitoring }\end{array}$ & $\begin{array}{l}\text { We recommend obtaining a complete blood } \\
\text { count (CBC) with platelet count, fibrinogen, } \\
\text { prothrombin time, D-dimer on admission } \\
\text { and serially for monitoring }\end{array}$ & 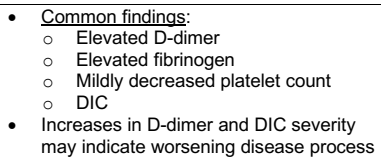 \\
\hline Imaging & $\begin{array}{l}\text { Baseline or surveillance imaging are not } \\
\text { recommended in the absence of clinical } \\
\text { symptoms of venous thromboembolism } \\
\text { Imaging may not be needed prior to } \\
\text { initiation of therapeutic anticoagulation if a } \\
\text { thromboembolic event or pulmonary } \\
\text { embolus is strongly suspected }\end{array}$ & $\begin{array}{l}\text { Type of imaging for diagnosis of VTE } \\
\text { should consider hospital epidemiologic } \\
\text { practices and risks of exposure during } \\
\text { transport and while obtaining the study }\end{array}$ \\
\hline $\begin{array}{l}\text { Risk Evaluation } \\
\text { for thrombosis }\end{array}$ & $\begin{array}{l}\text { We recommend that all pediatric patients } \\
\text { admitted for management of SARS-CoV-2 } \\
\text { infection be evaluated upon admission, and } \\
\text { daily thereafter for thrombotic risk and } \\
\text { We recommend that all patient patients at } \\
\text { risk for thrombosis with SARS-CoV-2 } \\
\text { infection be initiated on mechanical and/or } \\
\text { pharmacologic prophylaxis, if appropriate }\end{array}$ & $\begin{array}{ll}\text { - } & \text { Risk factors for thrombosis to consider: } \\
\circ & \text { Personal history of thrombophilia or } \\
& \text { VTE } \\
\circ & \text { First degree relative with VTE } \\
\circ & \text { Presence of central venous line } \\
\circ & \text { Post-pubertal age } \\
\circ & \text { Decreased mobility from baseline } \\
\circ & \text { Burns } \\
\circ & \text { Active malignancy } \\
\circ \quad \text { Indications of venous stasis or } \\
& \text { cardiac low flow state } \\
\circ & \text { Estrogen therapy } \\
\circ & \text { Active systemic infection } \\
\circ & \text { Flare of inflammatory disease } \\
\circ & \text { Obesity } \\
\circ & \text { Severe Dehydration } \\
\circ & \text { Recent surgery or trauma } \\
\end{array}$ \\
\hline $\begin{array}{l}\text { Pharmacologic } \\
\text { Management }\end{array}$ & $\begin{array}{l}\text { If pharmacologic prophylaxis is indicated, } \\
\text { we recommend low-molecular weight } \\
\text { heparin or unfractionated heparin over other } \\
\text { agents given more extensive pediatric } \\
\text { experience with heparin agents } \\
\text { Therapeutic anticoagulation is } \\
\text { recommended for patients receiving } \\
\text { anticoagulation therapy prior to admission } \\
\text { and for patients with highly suspected or } \\
\text { demonstrated VTE }\end{array}$ & $\begin{array}{l}\text { We do not recommend use of direct oral } \\
\text { anticoagulants due to limited data in } \\
\text { children and adults with COVID-19 }\end{array}$ \\
\hline $\begin{array}{l}\text { Thrombolytic } \\
\text { Therapy }\end{array}$ & $\begin{array}{l}\text { Thrombolytic therapy can be considered for } \\
\text { patients with a hemodynamically unstable } \\
\text { pulmonary embolus or limb threatening } \\
\text { deep vein thrombosis } \\
\text { Overall, we suggest that decision-making for } \\
\text { thrombolytic therapy be a coordinated } \\
\text { approach involving the critical care team, } \\
\text { hematologists and interventionalists }\end{array}$ & $\begin{array}{l}\text { Systemic alteplase may be preferred } \\
\text { over local mechanical thrombolysis given } \\
\text { the risk of exposure with transfer to and } \\
\text { utilization of an interventional suite, } \\
\text { however, contraindications to systemic } \\
\text { alteplase must also be considered }\end{array}$ \\
\hline
\end{tabular}

